\title{
An Investigation of NGOs' Role in Diminishing Poverty in Sindh
}

\author{
Sikandar Ali, Asif Ali Shah, Mahvish Khaskhely, Sahib Khatoon, \\ Muhammad Ilyas Abro, and Danish Latif
}

\section{ABSTRACT}

\begin{abstract}
Pakistan is a South Asian nation, where a significant portion is in the clutches of poverty characterized by a low standard of living as the country ranks $152^{\text {th }}$ in the global poverty index. Pakistan's government has been very keen on improving people's economic conditions in the region. NGOs are an essential part of civil society functions to fulfil the need for improvement in human development activities. While various NGOs are working in the country to eradicate poverty, but fruits have yet to be reaped. Thus, the main objective of the current study is to investigate efforts of NGO's intervened projects to bring forth the improvement in the living conditions of people. For data collection, quantitative methodology and structured questionnaire approach have been employed in the present study. Using the proportional distribution approach, a simple random sample of $\mathbf{3 0 0}$ respondents was drawn for this research analysis. The research was conducted keeping in view the poverty and similarity of the taluka's geographical and physical setups. For data collection, Sanghar's rural-talukas i-e Sinjhoro, Khipro, and Tando Adam were selected. The findings indicate that people of the Sanghar district were unhappy and pessimistic towards the NGOs' role in raising their standard of living. This shows concerns about their service delivery and support in the targeted geographical areas. Results also revealed that NGOs are unable to make people self-reliant and there is a need for a robust poverty alleviation strategy to lessen the poverty in the region. In conclusion, policy recommendations are provided, and areas of future studies are identified.
\end{abstract}

Keywords: NGOs, Global Poverty index, poor people, self-reliance, Sindh.
Submitted : February 15, 2021

Published : March 14, 2021

ISSN: $2507-1076$

DOI: $10.24018 /$ ejbmr.2021.6.2.754

Sikandar Ali *

MS HRM studen

Mehran University Institute of Science, Technology and Development, Jamshoro, Sindh, Pakistan.

(e-mail: alisikandar41@gmail.com)

Dr Asif Ali Shah

Associate Professor

Mehran University Institute of Science,

Technology and Development, Jamshoro, Sindh, Pakistan.

(e-mail: asifali.shah@faculty.muet.edu)

Mahvish Khaskhely

Lecturer

Mehran University Institute of Science,

Technology and Development, Jamshoro, Sindh, Pakistan.

(email:

mahvish.khaskhely@faculty.muet.edu.pk)

Sahib Khatoon

Assistant professor

Mehran University Engineering \&

Technology, Jamshoro, Sindh, Pakistan.

(email: sahib.khatoon@faculty.muet.edu.pk)

Muhammad Ilyas Abro

Assistant Professor

College Education Department, Government of Sindh, Pakistan.

(email: mohammadilyas.abro ${ }^{\circledR}$ yahoo.com)

Danish Latif

Lecturer

College Education Department, Government of Sindh, Pakistan.

(email: danishlatifnizamani@gmail.com)

*Corresponding Author

\section{INTRODUCTION}

Pakistan is a South Asian nation where a great number of poor people dwell. Also, Pakistan is currently contributing an extensive offer of about 21.5 percent of its population living below the projected need cap. This is the reason why neediness as an indispensable aspect of financial advancement is generally pulled in the light of a valid concern for academics and analysts having a position with Pakistan and South Asia [1].
Poverty has been a multifaceted phenomenon that is affected by social, political, and economic influences and these NGOs mostly have initiated poverty reduction programs within the communities that require either of their genre and other identifications [4].

Different governments took various measures for that reason. It also urged various NGOs to play their vital role in alleviating poverty. Nonetheless, the result obtained so far sadly is not promising. Poverty reduction targets are still illusory for Sindh in general and Rural District Sanghar in particular [12]. 
The development of NGOs over recent decades has given them an undeniably significant job in neediness decrease and network advancement. This has eventually driven them into framing an unmistakable part inside common society. This work was anticipated to some degree because of the belief that NGOs are productive and responsive to the problems of vulnerable communities, helpless grass-roots level, [6].

In the given conditions NGOs' work needs to be reviewed because when data was reviewed, this district has a greater number of NGOs in comparison to others. Some of the NGOs which started their programs from this district and expanded their programs in Sindh are also functional for three decades. The districts possess an old history of NGO intervention for poverty reduction in Sindh. Due to that Sanghar district is selected for the study of NGOs work. The role and functioning of NGOs are criticized and underweighted in Pakistan. The logic is that the sector is limited in certain areas where the majority of the funds are alleged to be utilized for vested interests.

\section{A. Research Gap}

This research can be called the groundbreaking research in terms of investigating the role of NGOs in the rural Sindh district Sanghar, and despite many NGO's are working in district Sanghar (Rural) but yet their role is not evaluated by the research or it has very little researched is to see the impact on poverty. This research's findings will fill that gap. Thus, the purpose of the current study is:

To analyze the change/improvement in living conditions of people with efforts of NGO intervened projects.

\section{B. Conceptual Framework}
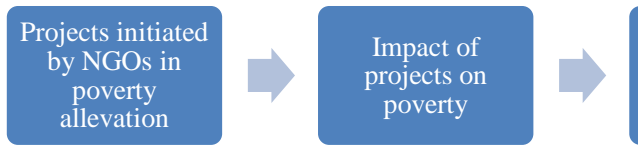
Meaures to
reduce poverty reduce poverty

Fig. 1. Conceptual framework.

\section{Significance of the Study}

The study evaluated the activities of NGO's working on poverty alleviation, achievements, and shortcomings of these NGOs in the delivery of microcredit in decreasing the poverty situation in Sindh, by knowing the extent of poverty and inequality, and identifying the correlates and other socioeconomic characteristics among the people in the study area. This study has brought the ground realities in front of the policymakers and the NGO managers to play their role appropriately and comprehensively to diminish the poverty problem in Pakistan.

\section{LITERATURE REVIEW}

\section{A. Non-Governmental Organizations (NGOs)}

Non-governmental organizations (NGOs) encompass several civil society groups, and so, its simple meaning remains questioned. Nonetheless, NGOs are also referred to as private, voluntary, and non-profit organizations undertaking programs aimed at mitigating poverty, supporting the welfare of the poor, protecting the atmosphere, delivering crucially important social services, or promoting community development based on the values of humanitarianism and the philosophy of voluntarism [8].

In most developing countries, NGOs provide between 14 to 50 percent of both curative and preventive health and medical services in terms of providing affordable health care for the poor. NGOs tend to achieve attention in both the health and education sectors through the implementation of complementary programs to help the state's endeavor to address the underserved in rural deprived communities [7].

Compared with the size of the vulnerable community, the overall coverage of NGOs at present is comparatively small. The NGOs allocated the proportion of loans to the total population group received by 0.8 percent in urban areas and 1 percent in rural areas, according to the NHDR / PIDE reported in 2001.

Similarly, the NRSP functions in 27 districts and is by far the country's biggest NGO, with a cumulative range of just 293,000 beneficiaries. The NHDR / AI survey shows that there is a significant gap between the different NGOs in the effectiveness of poor targeting and the effects of the intervention on poor people's education, nutrition, and health [9].

NGOs that have promoted the growth of individual poor citizens' organizations should play a critical role in creating a structural relationship between poor people and local governments. This partnership would enable poor people communities to participate in planning and executing construction programs, as well as business access decisions and municipal power systems. Equally important will be the need to focus on creating regional NGOs in a large number of districts with a limited coverage area and high overhead costs in each district-specific NGO to ensure maximum coverage of the poor community in that district's cities, union councils, and tehsils [5].

\section{B. International Perspective on Poverty}

9.2 percent of the world's population lived on less than $\$ 1.90$ a day in 2017, down from around 10.1 percent in 2015 according to the latest figures. Progress has been inconsistent and an unacceptably high number of people left in severe poverty. World Bank said world poverty exceeded 10 percent. That means equivalent to 689 million people who inhabit the planet live on or below the poverty line [3].

Poverty is beatable. Poverty remained for years and would continue to exist unless there is an international agenda of equality and 'just social order' in the world. Poverty is a perplexing and humiliating issue. This has not been in the past and is not likely to be introduced by the leading powers. The vested interest prevails whether it is the question of international rates of interests or the technological developments and royalty earned thereon. This objective can be achieved by a country, community, or the world however it needs concerted efforts, a transparent approach, good governance, and adequate infrastructure like health, education, available well-nourished diet, and water. The World Bank and other international organizations and lending institutions are doing their best for this poverty alleviation programs. UNDP has put up different Millennium Development Goals and the member countries have signed the MGD treaty [13]. 
There has been tremendous economic development over the past half a century when Europe, Japan, the USA, and few other countries in Asia, Europe, and North America turned into be superpowers in the economic sphere. Changes continued happening in the development vista while the USA dominated its best proposition and place as the superpower in terms of defense and the economy [4].

The global economy is now directly or indirectly controlled by the USA including that of international organizations like the World Bank, International Monetary Fund, etc. With many resources lying in the hands of leading few countries while a majority of the population says around 50 percent of an entire population is under poverty clutches. According to the World Development Report of the United Nations, the control over the global wealth is at the hands of the USA and its allies while a majority of Asian and African countries are suffering from less than 2 dollars a day [10].

This calculation itself reflects that how the World Bank works for "the world free of poverty" where economists continue working for research and suggesting remedial measures, however, the inequitable distribution of resources and income are the fundamental issues [10].

\section{Poverty in Sindh}

Many rural settlers in the district of Sanghar, Kohli, Punjabi, and Bheel turned out to have a very high incidence of deprivation. The Sanghar's Kohli and Bheel infringe on the lowest single class in the deprivation ranks of cross villages. The Punjabi had become landless landlords for immigrants from the south of Punjab. Baloch and Sammat had to some degree been comparatively poor with the two Mir Kinship classes among the left; the Baloch 1 and Sammat were less likely to be weak. Among the worst ones were the Khaskhely too. Population poverty rates in Sanghar have proved to be among the lowest among the Hindus and scheduled castes. The Mir's' relative success was in line with their typically comfortable position, but the historically weak Khaskhely managed to do almost as well as the Mir's [12].

The socio-economic growth environment is the state's key responsibility in resource-obliging nations. If the governments have different restrictions, this can be accomplished by all sections of society working together. The constrained capacities of the administrations have made it hard to react adequately to the developing needs of the population at a grassroots level. The question of what different measures ought to be embraced for improvement of the population, the pragmatic methodologies appear to have organization and advancement of NGOs in the district. In this association, many different, national, local and communitybased NGOs are working in the area with numerous goals to redress poverty, enhance health and education, and informally education to the people of district Sanghar.

NGOs are rising quickly in numbers and zones, but their possibilities remained unused due to the in-credulity against their role. They are important actors in economic development and in alleviating deprivation through their small-scale funding programs. The NGOs are of different types, such as funding from community-based groups, intermediaries, and NGOs / international. They share the same goal of helping people build self-sustainable socioeconomic projects despite the various rates they perform at.

\section{RESEARCH METHODOLOGY}

The work is descriptive and has been carried out empirically. Primary data is obtained from key individuals and households in the target group through interviews, surveys, and personal experiences. Secondary data was collected by studying the desk. Complete 300-household samples from Sanghar districts were selected. For data collection, a structured questionnaire approach has been employed in the present study. Using the proportional distribution approach, a simple random sample of 300 respondents was drawn for this research analysis.

\section{A. Sample and Context of the Study}

The present study was conducted in selected three talukas of district Sanghar only due to lack of financial resources and limited time. The overall district has six taluka i.e. Sanghar, Khipro, JamNawazali, Tando Adam, Shahdadpur, and Sinjhoro. The research was conducted keeping in view poverty and the similarity of the taluka geographical and physical setups. For data collection taluka Sinjhoro, Khipro, and Tando Adam have been selected.

\section{DATA ANALYSIS}

\section{A. Social \& Welfare Service Facility}

The availability of social and welfare facilities is the basic need of everyone in the country. The data regarding social and welfare centers in the study area is collected and the result disclosed that in district Sanghar majority of people of the villages are deprived of social and welfare services. The survey result (Table 1) clearly shows that 66.7 percent of respondent agreed that the social and welfare center was, "Not known", not available, 5.0 percent respondent replied "No", 5.3 percent respondent agreed that they "Little bit" availed service, 8.7 percent respondent agreed that they "Fairly" availed service and while only 14.3 percent respondent agreed that they "Benefited" and availed social and welfare service.

TABLE 1: SOCIAL \& WELFARE SER VICE FACILITY

\begin{tabular}{cccc}
\hline Response & Frequency & Percent & Cumulative Percent \\
\hline Not known & 200 & 66.7 & 66.7 \\
No & 15 & 5 & 71.7 \\
Little bit & 16 & 5.3 & 77 \\
Fairly & 26 & 8.7 & 85.7 \\
Benefited & 43 & 14.3 & 100 \\
Total & 300 & 100 & \\
\hline
\end{tabular}

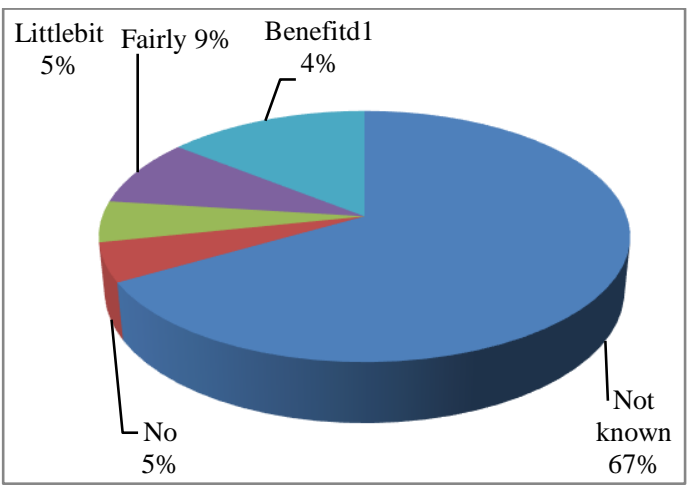

Fig. 1. Social \& welfare service facility 


\section{B. NGO Run School}

The purpose of education programs by NGOs is to educate the children who were not enrolled or dropped out of school. In rural areas, people prefer to send their children to the field rather than to school due to lower basic educational facilities. Data regarding the availability of NGOs running schools in the study area revealed that "NGOs RUN SCHOOL" play somehow role in primary education. The survey result (Table 2) revealed that 34.0 percent respondents responded "Not Known", 12.7 responded "No", 21\% responded that they availed "Little bit", 19\% responded that availed "Fairly" and only $13.3 \%$ respondents replied they "Benefitted" from the NGO run school.

\begin{tabular}{cccc}
\multicolumn{4}{c}{ TABLE 2: NGO RUN SCHOOL } \\
\hline Response & Frequency & Percent & Cumulative Percent \\
\hline Not known & 102 & 34 & 34 \\
No & 38 & 12.7 & 46.7 \\
Little bit & 63 & 21 & 67.7 \\
Fairly & 57 & 19 & 86.7 \\
Benefited & 40 & 13.3 & 100 \\
Total & 300 & 100 & \\
\hline
\end{tabular}

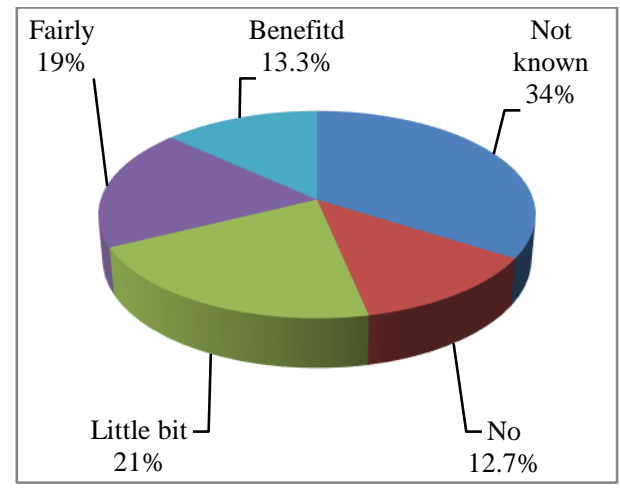

Fig. 2. NGO Run School.

\section{Free Ration Distribution}

In villages, most of the people are very poor and they could not fulfill their children's basic needs because of their limited economic resources. Sometimes, NGOs and philanthropists provide them free ration for their livelihood. At that period, they feel economically strong and better. That is not a good sign for their status because that indicates that they remain poor throughout the year. The survey result (Table 3 ) revealed shows clearly that 33.3 percent of respondents couldn't get free ration and responded "Not known", 20.0 percent responded "No", 16.7 percent responded "Little bit", 16.3 percent responded that "Fairly" availed and while only 13.7 percent respondents responded that they "Benefited".

TABLE 3: FREE RATION DISTRIBUTION

\begin{tabular}{cccc}
\hline Response & Frequency & Percent & Cumulative Percent \\
\hline Not known & 100 & 33.3 & 33.3 \\
No & 60 & 20 & 53.3 \\
Little bit & 50 & 16.7 & 70 \\
Fairly & 49 & 16.3 & 86.3 \\
Benefited & 41 & 13.7 & 100 \\
Total & 300 & 100 & \\
\hline
\end{tabular}

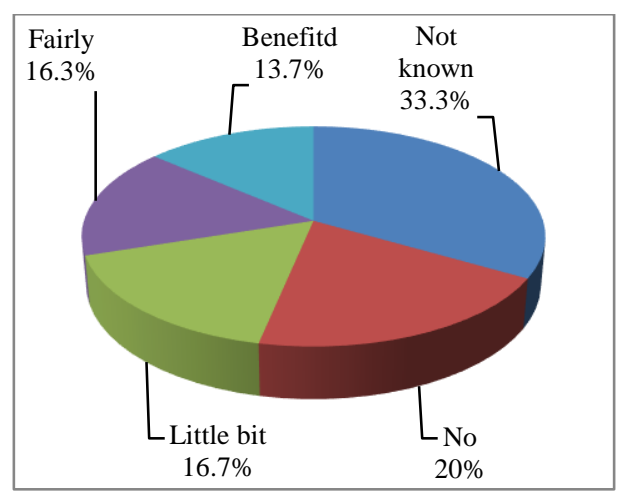

Fig. 3. Free ration distribution.

\section{Cash for Work Program}

The role and functioning of NGOs are criticized and underweighted in Pakistan. The logic is that the sector is limited in certain areas where the majority of the funds are alleged to be utilized for vested interests. The mostly NGOs are locally working in limited areas and supported by local philanthropists. Sometimes, NGOs and philanthropists provide cash for work programs to them. The survey result (Table 4) demonstrates indicates explicitly that almost all of the respondents' opinion was that NGOs are not supporting to make the people self-sufficient.

TABLE 4: CASH FOR WORK PROGRAM

\begin{tabular}{cccc}
\hline Response & Frequency & Percent & Cumulative Percent \\
\hline Not known & 300 & 100 & 100 \\
\hline
\end{tabular}

\section{E. Role of $\mathrm{NGOs}$}

The survey result (Table 5) shows clearly that larger numbers of respondents were satisfied somewhat by the role of NGOs toward human development. The public generally is eager to get something that could help them in smooth financial transactions. The recipients have also a piece of limited knowledge about the functioning and total budget allocation for those NGOs. Therefore, they never raise voice against them such a practice can deprive of the money they are receiving.

\begin{tabular}{cccc}
\multicolumn{4}{c}{ TABLE 5: RoLE OF NGOS } \\
\hline Response & Frequency & Percent & Cumulative Percent \\
\hline Yes & 52 & 17.3 & 17.3 \\
No & 119 & 39.7 & 57 \\
To some extent & 129 & 43 & 100 \\
Total & 300 & 100 & \\
\hline
\end{tabular}

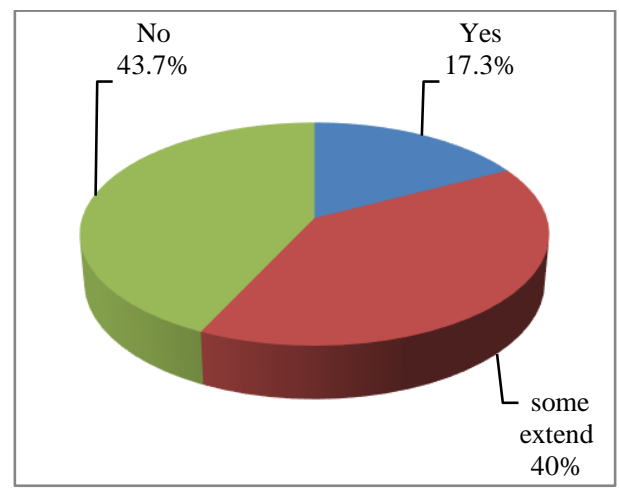

Fig. 4. Role of NGOS. 


\section{F. Poverty Decreased After NGOs Intervention}

The survey result (Table 6) shows clearly that greater numbers of respondents stated that their economic condition is very stagnant. Sometimes the NGOs and philanthropists give them financial assistance. At that time they feel better economically. But on the whole, their status is dormant. That indicates that throughout the year they remain poor.

TABLE 6: POVERTY DECREASED AFTER NGOS INTERVENTION

\begin{tabular}{cccc}
\hline Response & Frequency & Percent & Cumulative Percent \\
\hline Much & 31 & 10.3 & 10.3 \\
Very little & 153 & 51 & 61.3 \\
No effect & 116 & 38.7 & 100 \\
Total & 300 & 100 & \\
\hline
\end{tabular}

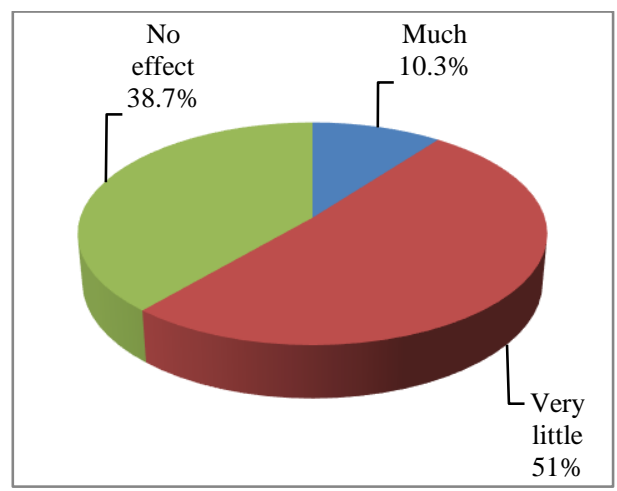

Fig. 5. Poverty decreased after NGOS intervention.

\section{ANALYSIS FOR HYPOTHESIS}

\section{A. Hypothesis 1}

Ho: No association between financial support of NGOs and poverty. H1: Financial support of NGOs is likely to be associated with poverty.

For the data given in hypothesis Table 7, the independence test was used to determine relationship between two variables. To test the independence of the two variables, the chi-square test is applied. With 6 degrees of freedom, the chisquare value is 12.014. Ho is, thus, accepted and H1 is rejected. Therefore, it is concluded that the financial aid of NGOs have no direct effect on alleviating poverty. The resulting $\mathrm{p}$-value is about 0.062 . This means that the variables are independent or there is no a significant interaction between the variables. Since the chi-square test rejects the model of variable dependent.

\begin{tabular}{cccc}
\multicolumn{4}{c}{ TABLE 7: CHI-SQUARE TESTS } \\
\hline & Value & $\begin{array}{c}\text { Degree of } \\
\text { freedom }\end{array}$ & $\begin{array}{c}\text { Asymptotic } \\
\text { Significance (2-sided) }\end{array}$ \\
\hline Pearson Chi-Square & $12.014^{\mathrm{a}}$ & 6 & .062 \\
Likelihood Ratio & 11.949 & 6 & .063 \\
Linear-by-Linear & 1.052 & 1 & .305 \\
$\quad \begin{array}{c}\text { Association } \\
\text { N of Valid Cases }\end{array}$ & 300 & & \\
\hline
\end{tabular}

\section{B. Hypothesis 2}

Ho: No association between occupation of respondents and poverty. H1: Occupation of respondents is likely to be associated with poverty.

The second test of hypothesis described that there is no association between occupation of household source and poverty. In order to test the independence of the two variables, the chi-square test is applied. The chi-square value is 5.413 with 15 degrees of independence. Around 0.988 is the resulting p-value. Accordingly $\mathrm{Ho}$ is accepted and $\mathrm{H} 1$ rejected. This means that the variables are independent or that the variables have no significant association. Since the chisquare test accepted the component independency model.

\begin{tabular}{cccc}
\multicolumn{4}{c}{ TABLE 8: CHI-SQUARE TEST } \\
\hline & Value & $\begin{array}{c}\text { Degree of } \\
\text { freedom }\end{array}$ & $\begin{array}{c}\text { Asymptotic } \\
\text { Significance (2-sided) }\end{array}$ \\
\hline Pearson Chi-Square & $5.413^{\mathrm{a}}$ & 15 & .988 \\
Likelihood Ratio & 6.065 & 15 & .979 \\
Linear-by-Linear & .263 & 1 & .608 \\
Association & 300 & & \\
N of Valid Cases & & & \\
\hline
\end{tabular}

\section{CONCLUSION}

It is identified that the major reason for poverty in district Sanghar is the lack of skills and knowledge among common people for the proper utilization of available resources. Sometimes the NGOs and philanthropists give them financial assistance. At that time, they feel better economically. But overall, their status is dormant. That indicates that throughout the year they remain poor. In Pakistan, the role of NGOs towards human development is underweighted and criticized. The logic is that the sector is limited in certain areas where most of the funds are alleged to be used for vested interests. In villages, mainly people come to know about NGOs when their relatives are recipients of monetary aid, whereas their other contribution to human development elements such as poverty reduction is mostly negligible.

\section{STUdy CONTRIBUTIONS}

This study offers many contributions i.e.:

The findings have demonstrated that NGOs must be selective in doing only those activities, which are feasible to intervene at the grassroots level, and can be managed easily. Such activities could be the creation of awareness and development of human resources rather than distributionoriented activities. Similarly, it also requires smooth collaboration and co-ordination among intervening organizations that are working for the same purpose to create a synergy of efforts for implementing different activities successfully. NGOs should also develop their capability for utilizing local resources and implementing their programs more effectively.

\section{FUTURE RECOMMENDATIONS}

This research has brought many recommendations as:

1. Research should be done on that how NGOs establish working relationships for the smooth functioning of poverty alleviation programs with different agencies.

2. Donor Organizations (VDOs and NGOs) create enough capacity to update and enhance human capital through quality education, safety, and environmental conditions.

3. NGOs, along with wealthy people and philanthropists, must build homes for all those affected by floods and earthquakes and provide them with income-generating business loan facilities. 
4. NGOs and Government jointly should set up elementary and higher secondary schools for girls in the study area.

5. Loan processes are difficult for traditional financial institutions; they should be streamlined and ideally converted into local languages such as Urdu, Sindhi, and Baluoch and Punjabi languages.

5. NGOs / VDOs must promote the implementation of new farming technology to help farmers improve and increase the yield, in order to boost their living standards.

7. NGOs in their respective communities should address the real problems the poor faces.

8. This research work should be replicated time and time again to determine the number, severity dimension, and complexity of poverty issues that may emerge over time in Sanghar Districts.

\section{REFERENCES:}

[1] Iqbal, N. (2020). National Poverty Estimates 2018-19.

[2] Memon, Q. U. A., Wagan, S. A., Chunyu, D., Shuangxi, X., \&Jingdong, L. (2019). An Analysis of Poverty Situation of Landless Peasants: Evidence from Sindh Paki-stan. Journal of Poverty, 23(4), 269-281.

[3] World Bank, 2020.

[4] Abbas, S. K., Hassan, H. A., Asif, J., \& Zainab, F. (2018). How Income Level Distribution Responds to Poverty: Empirical Evidence from Pakistan. Global Scientific Journals, 6(3), 131142

[5] Jamal, H. (2017). Poverty and Vulnerability Estimates: Pakistan, 2016. Social Policy and Development Centre.

[6] Mirza, A., Shaikh, N., Talpur, U., \& Khaskheli, A. Z. (2016). Impact of Ngos In Poverty Alleviation: A Case Study of Badin District. The Women-Annual Research Journal of Gender Studies, 8(8).

[7] Shah, F. (2016). The rise of NGOs and their harmful impact on Pakistan. The Monthly Herald, Karachi, Pakistan.

[8] Gul, W. (2015). Role of NGOs in Education from Pakistani Context. Journal on Innovation and Sustainability. RISUS ISSN 2179-3565, 6(2), 139-145.

[9] Jamali, M. B., Shah, S. M. Z., Shah, A. A., Shafique, K., \& Shaikh, F. M. (2011). Impact Analysis of Public Sector and NGO's to Improvement of Rural Livelihoods in Sindh. International Journal of Business and Management, 6(2), 236.

[10] Khan, F. A., \& Ullah, K. (2015). Factors Contributing Towards Rural Poverty (A Case Study of Upper Sindh, Pakistan).

[11] Ahmad, R. I. (2013). Rural Development, Economic Growth, and Poverty: Evidence from Pakistan (Doctoral dissertation, Bahau-ddin Zakariya University, Multan.).

[12] Anka, L. M. (2009). An empirical analysis of the determinants of rural poverty in Sindh province of Pakistan (Doctoral dissertation, University of Sindh Jamshoro Sindh Pakistan).

[13] UNDP, 2018. 